\title{
Research on the Influence of Undergraduates Participating in "Gig Economy" on Their Employment and Entrepreneurship
}

\author{
SenYANG ${ }^{1, a}$, Hong-Zhen LIN ${ }^{1, b, *}$, Yong-Zhou HUANG ${ }^{1, c}$, \\ Gui-Dan XU ${ }^{1, d}$, Ying-Jue DU $U^{1, e}$ \\ ${ }^{1}$ School of Hengda Management, Wuhan University of Science and Technology Wuhan, China \\ 947 He Ping Street, Hubei Wuhan 430081, China \\ a8392806422@qq.com, blinhongzhen@126.com, ${ }^{c}$ 857952176@qq.com, \\ d284235439@qq.com, ${ }^{\mathrm{e}} 1034250034 @ q q . c o m$
}

Keywords: Internet, Gig economy, Labor force, Economic law, Employment, Entrepreneurship.

\begin{abstract}
The purpose of this paper is to research the influence of undergraduates participating in "Gig Economy" on their employment and entrepreneurship. Using the method of questionnaires and interviews, document study deeply, correctly understand and analyze the problem. Through the research on the labor market, labor relations in the Internet era, innovation and entrepreneurship policies and the Internet environment, the relationship between undergraduate students' participation in gig economy and college students' employment and entrepreneurship is analyzed. The conclusion is that gig economy promotes economic development, provides jobs and help college students start their own business.
\end{abstract}

\section{Introduction}

According to the survey results, the total number of graduates in 2012 was 6.71 million, and 68.5\% of the total students chose to work.Many students do not pay special attention to the employment situation during school. Some students think that employment is a very annoying thing. Therefore, they are not willing to consider this matter and avoid reality. Most of the college students do not have any plans and plans or plans for their future career. They are not even considered. This is a very important reason for employment difficulties.

Recent graduates have many different employment options downstream from employment pressure. According to Internet surveys, $59.15 \%$ of graduates choose to work in state-owned enterprises (stable and well-being), and $39.89 \%$ of graduates choose to work in private companies. According to the classification of the three major industries, $23.1 \%$ of graduates chose agriculture, $38.4 \%$ of graduates chose industrial enterprises, and $37.7 \%$ of graduates chose business services.

The graduates have a strong desire for economic independence while facing the society, and they are facing rising house prices and consumer demand, which has led to the emergence of abundant visible benefits as the primary aspirations of graduates. Second, university students also hope that they can use what they have learned in their work and sharpen their own knowledge and have a broader platform for development. These two important appeals are the key for graduates to choose employment. According to the statistics of online surveys, the employment demands of recent graduates include: career development appeals, economic interest appeals, regional environmental appeals, hobbies and appeals, and so on. Data show that $35.15 \%$ of graduates put economic interests first, $32.48 \%$ of graduates put career development first, $17.54 \%$ of graduates chose a geographical environment, and $9.14 \%$ of graduates chose hobbies and interests as the first appeal.

\section{The Analysis of the Network Workforce Market}

\section{Firstly, Comparison between Traditional Labor Market and Internet Labor Market}

The information on supply and demand in the traditional workplace labor market is not sufficient. The presence of structural imbalances and frictions limits the number of formal employment; the information on the labor market in the Internet platform is sufficient, and the supply and demand 
information is connected in a timely manner and the effective allocation is greatly reduced. Transaction costs create a large number of flexible jobs. [1]

Labor and capital in the traditional workplace labor market have a single correspondence under the legal rules. They maintain a long-term, stable ownership relationship through contract management; the employers and employees of the labor market in the online platform participate in multiple, flexible concepts at the same time with a shared concept. In the contractual relationship.

Enterprises in the traditional workplace labor market emphasize the ownership and control of labor, manage laborers through scientific management methods, and pay attention to the completion of work processes; while companies in the online platform labor market "do not ask for everything, but use it", Pay attention to the role of the professionalism of workers in the task.

Laborers in the traditional workplace labor market are hired by the company to complete tasks assigned by the company in accordance with standardized workflows; while laborers in the online platform labor market participate in the design, production, and sales of enterprise products and services in an autonomous manner. In the process.

The traditional workplace labor market is under a relatively mature legal system, the government establishes coordination mechanisms such as tripartite consultations and collective bargaining, and for the online platform labor market, the legal system has not yet been established, and it has also become a source of contention.

\section{Secondly, Assumption of Platform Construction}

The industrial chain is formed in the network platform. The enterprise reflects the skills of the laborers on the platform and forms a stable and expanding cluster of industrial workers. When workers re-employed, there is no need for repeated skills training, which greatly improves employment efficiency and ensures production efficiency and quality. The employment needs of the same industry and enterprise or the industrial worker group that masters the skills of certain industries can quickly and accurately retrieve and exchange information through the platform.

The network platform for supply and demand information. Most workers change their jobs frequently and re-employ themselves after a short period of adaptation and work. However, because they do not understand the specific information of the workplace, they often run into trouble in the odd-turning market. The release of labor recruitment information for labor companies is relatively simple, which creates barriers for communication between the two parties and will inevitably result in the loss of large numbers of laborers after they have been employed. Therefore, the construction of an internet workforce platform must define the quantification and precision of demand information. [2]

Convenient and efficient network platform. Most of the part-time labor market is 80 years old. Basically, it can proficiently use the network and the current mainstream mobile communication methods, and half of the surveyed people indicated that they are willing to learn information on employment units and find jobs through the Internet, SMS, or WeChat. Therefore, it is possible to reduce the cycle of information retrieval and information transmission through mobile Internet terminals and make use of apps with a high degree of public awareness, thereby bringing about an efficient platform for laborers and employers.

Establish a platform with high credibility and reputation. Due to the rapid development of the Internet and the widespread dissemination of information, employment information is mixed, often with some false information and illegal practices (such as illegal recruitment, etc.), which greatly reduces the safety and security of workers. Therefore, the most important step in the process of building a platform is to involve the government, engage in information retrieval by employers and laborers, and avoid the appearance of fraudulent and illegal information and behaviors. Only in this way can the basic interests and security of the supply and demand sides be guaranteed. In general, government departments are the core, and operators are the backbone of technology. They comprehensively consider the application needs of enterprises, communities, and laborers. 


\title{
College Students Employment and Entrepreneurship Status
}

\author{
Firstly, The Social Status of College Students' Employment Difficulties \\ The Number of Graduates is a Record High - "the Hardest Job Season"
}

According to information released by the Ministry of Education, the number of college graduates in 2017 reached 7.75 million, exceeding the 7.65 million in 2016, and the college graduates were highly innovative; at the same time, according to the news of the Ministry of Education, together with graduates of secondary vocational schools and students not yet employed in 2016 The number of unemployed people this year will reach 15 million, which is called "the most difficult employment season." [3]

\section{The Proportion of Undergraduate Entrepreneurship Increases Year By Year but the Success Rate Is Low}

Under the background of "mass entrepreneurship and innovation," more and more college students have embarked on the road to self-employment. College students According to data from the 2017 China Undergraduate Employment Report published recently by the Max Institute and the Chinese Academy of Social Sciences, in the past five years, the number of undergraduates who graduated from the business has continuously risen from 1.6\% in 2011 to 3.0\% in 2017. . Based on the total number of 7.95 million new graduates in 2017, the number of entrepreneurial students in the year exceeds 200,000. However, the data also shows that the average success rate of Chinese college students is $2 \%$, and even the highest success rate of national college students in China is only $4 \%-5 \%$, which is ten times worse than the $20 \%$ success rate of college students in Europe and America. [4]

\section{Secondly, Causes of Difficulties in Employment and Entrepreneurship for College Students}

Unbalanced supply and demand. With the continuous expansion of enrollment in colleges and universities, the phenomenon of "popularization" of college students has emerged and the number of college graduates has increased year after year. As for the upgrading of industrial structure, the development of the tertiary industry, and the optimization of the market environment of the secondary industry, the slowdown in the growth of the secondary industry has caused some areas Demand for talent decreased. At the same time, the slowdown in economic growth in recent years has created a small "weakness" in society as a major cause. Many factors have caused the imbalance between talent supply and demand.[5]

Productivity development and technological progress. College students, as the laborers in the production factors, their labor levels affect the development of productivity. Due to the social transformation of scientific and technological progress, the social market places higher demands on the labor force level. Under the rigid education system, the knowledge level and practical ability of some undergraduates are not up to the level of social needs, science and technology reject the "non-compliance labor force," and there is a "labour surplus". [6]

Contemporary college students lack "core competence". Due to the institutional education of the school and the college students' lack of self-effort, the college students are very lacking in employment and entrepreneurship, lack the relevant professional abilities and accomplishments, and fail to meet the requirements of modern enterprises. At the same time, some college students have the wrong concept of employment, "they are low-handed and over-pursued for freedom," and most newly graduated students appear impetuous, which is not conducive to their employment and entrepreneurship. In addition, there are shortcomings such as lack of funds, weak management capabilities, and lack of social resources in college students' entrepreneurial ventures, making them repeatedly frustrated in their undertakings. [7]

\section{Effect of Part-time Workers' Economy on Innovation and Entrepreneurship of University Students}

A gig economy emerged as a new economic business model. Through the Internet and mobile 
technologies, the rapid match between the unemployed labor force and talented companies is greatly improved. It not only satisfies the company's talent demand, enables its production to be carried out, and thus makes it profitable and sustainable; it also satisfies the need for laborers to seek work and obtain labor remuneration, thus ensuring their lives. Finally, the balance of supply and demand between the two sides has enabled social reproduction to proceed smoothly and has greatly spurred the vitality of society and economy.

At the same time, the odd-turn economy is not only a form of economic activity, but also a new model of "short-term contracts, on-demand employees". For enterprises, there is no need to provide employees with long-term support and pay five insurance premiums for them, which greatly reduces the situation of "helpless uselessness", greatly reduces the production and labor costs of enterprises, and increases profits. For job-seekers, especially for newly-graduated freshmen, there is a strong interest in the Internet. The work focuses on interest, freedom, and does not like being bound by the boss and the company. This way of looking for work through the Internet, it is clear that they accept each other's "short-term contracts with people." The appearance of this new economic model has promoted the development of the social economy. The increase in demand for short-term hired employees of enterprises has also provided more suitable jobs for college students. [8]

In recent years, higher education has placed greater emphasis on improving the overall quality of college students and a new model of "school-enterprise cooperation" has emerged. Through the cooperation of schools and enterprises, companies are allowed to enter the campus for publicity and recruitment; students enter the company, short-term internships, and part-time jobs. Through the students' self-perception in the work process, on-site task experience, consult and learn, understand the professional skills and literacy that enterprises need to achieve their social resilience. At the same time, the related suggestions made by companies for schools and enterprises are also conducive to the school's change in the rigid education system and personnel training. In a certain sense, school-enterprise cooperation is also a form of participation of college students in the gig economy. Its participation process and understanding of modern enterprises and modern society promote the development of students' modern awareness and work experience. Ultimately improve the students' core competitiveness and enhance their ability to start employment. [9]

The lower production and employment costs of the "short-term contract, on-demand employee" model of the gig economy referred to in the previous article must be their first choice for college students who have just entered the society or started their own business at the time of school. The best choice.

Students through the early participation in the gig economy, the company's work experience, corporate culture, management strategy understanding, as well as understanding of the company's modern thinking, to solve the entrepreneurial "lack of management experience and social awareness" of the problem. [10]

\section{Conclusions}

Gig economy promotes economic development and provides jobs. The odd jobs market has become a way for college students to improve their core competitiveness. Gig economy has become the choice for many college students to start their own businesses. The gig economy means that the number of temporary jobs surges. At the same time, it means that work pay is lower, benefits are less, and stability is worse. Workers are different. Some people are keen on the flexibility and rewards offered by this kind of work. Some people are forced to engage in casual or unpaid workforces or agency workers. Most people still prefer a fixed contract instead of a continuous temporary job

\section{Acknowledgement}

This research was financially supported by the project of innovative and entrepreneurial training program for provincial university students in Hubei in 2017: Study on the influence on their 
employment and Entrepreneurship of the college students' participation in the zero work economy, NO: 201710488037

\section{References}

[1] JiWenwen, Lai Desheng. Analysis of the Impact Mechanism and Practice of Employment on Labor Relations on Internet Platform [J]. Journal of China Institute of Industrial Relations, 2016(4):6-16. (In Chinese)

[2] Wang Yuhan. Talking about the slash youth and the gig economy [J]. Chinese Commercial Theory, 2017(35): 189-191. (In Chinese)

[3] The Survey Group of China University Students Employment Status Survey Report on the Employment Situation of Chinese University Students in 2016[J]. China University Student Employment, 2017(14):34-41. (In Chinese)

[4] Zhao Tengda, HuoYanmin. Gig-employment Economy Leads the Change in Employment Market [J]. Shanghai Information Technology, 2017(4):64-66.(In Chinese)

[5] Peter Ward. Future work: Part-time economy and its limitations [R]. From the Think Tank Policy Institute of Korea Think Tank, 2017

[6] Ancestral hall. The popular "gig economy" Your future direction of nuggets [N]. Entrepreneurial focus.

[7] Wang Lijun. China's share of economic development issues and countermeasures [J]. Academia, 2016 (12): 225-232.(In Chinese)

[8] Liao Liangliang. Freedom vs. Unstable, joy and worry of odd-job practitioners - "Gig economy era, everyone is freelancer" [J]. New Oriental English: Chinese/English version, 2017(10): 1-1.(In Chinese)

[9] Liu Ye, Li Ming. Analysis of Labor Relations Changes in Economic Model under Network Productivity [J]. Economist, 2017(12):33-41.(In Chinese)

[10] Wang Ying. "The Messy” in the Part-time Economy [J]. Shanghai Information Technology, 2018(1):64-66.(In Chinese) 